\title{
THE EXTRALINGUISTIC FACTORS ON THE INTRALINGUAL TRANSLATIONS OF 'PERSON REFERENT ELLIPSIS' IN CLASSICAL JAPANESE
}

\author{
KLASIKK JAPONCADAKİ KISŞİ BİLDİREN YAPILARDAKİ EKSİLTINNIN DİLİÇİ \\ ÇEVIRILILRINNDE DİL DIŞI ETMENLER
}

\begin{abstract}
Esin ESEN ${ }^{1}$
Abstract

This study addresses the differences in 'person referent' ellipsis in four different intralingual translations of a classical Japanese text titled Murasaki Shikibu Nikki [The Diary of Lady Murasaki] (1008-1010), which date from 1918, 1933, 1954 and 1965 accordingly. This study aims to reveal the extralinguistic factors that effected the changes seen in the different intralingual translations regarding the 'person referent' ellipsis. Firstly it is focused to the factors effected the changes in Japanese. Then the text analysis is applied. The data gathered from text analysis have been construed in the light of extralinguistic factors. The following results are reached: a) 1918 translation reflects the influence of language polices such as standard language and unification of written and spoken language, while a close connection reflects with classical language, b) 1933 translation is on the border line with previous language policies and militarist language policies, c) 1954 translation shows a transition between militarist language policies to American occupation language policies in Japan, d) 1965 translation is an example of the Western influence after the American occupation. This investigation not only contributes to translation studies in the context of Japanese and intralingual translations, but also to the studies on Lady Murasaki, her diary, and the studies on classical Japanese literature.
\end{abstract}

Keywords: Intralingual translation, 'Person referent ellipsis', Language policies, Murasaki Shikibu, Classical Japanese

$\ddot{O} z$

Bu çalışmada klasik Japoncadaki kişi bildiren yapılardaki eksilti, Japon edebiyatının ünlü yazarının eseri Murasaki Shikibu Nikki [Murasaki Shikibu'nun Günlüğü] (1008-1010) bağlamında ele alınmış, kaynak metinde tespit edilen eksiltiler eserin 1918, 1933, 1954 ve 1965'e tarihlenen dört ayrı diliçi çevirisiyle karşılaştırılmıştır. Konu dilbilim çalışmalarıyla yakından ilgili gözükse de, çalı̧̧mada kişi bildiren yapılardaki eksiltinin değişiminde dildışı etmenlerin olduğu savıyla yola çıkılmış ve çalışmanın sonucunda bu etmenler ortaya konulmuştur. Öncelikle örneklemi oluşturan dönemde Japon dilindeki değişimlere etki eden etmenler incelenmiş, yapılan metin analizi ve beş metnin karşılaştırılmasıyla elde edilen sayısal veriler bu açıdan yorumlanmıştır. Elde edilen sonuçlar şöyledir: a) 1918 çevirisinde standart dil, yazı ve konuşma dilinin birleştirilmesi gibi dil politikalarının etkisi görülmüştür b) 1933 çevirisi önceki dil politikalarından, militarist döneminin dil politikalarına geçişi yansıttığı tespit edilmiştir. c) 1954 çevirisinde militarist dil politikalarından Amerikan işgal dönemi etkisinde oluşturulan dil politikalarına geçişin etkisi bulunduğu görülmüştür. d) 1965 çevirisi ise Amerikan işgal döneminden sonraki Batı etkisinin bir örneğini gösterdiği sonucuna ulaşılmıştır. Bu çalışma Murasaki Shikibu'nun Günlüğü'nü bu konuda ele alan ilk çalışmalardan biri olarak, çeviribilim, diliçi çeviri çalışmaları ve klasik Japon edebiyatı çalışmalarına katkıda bulunma hedefiyle oluşturulmuştur.

Anahtar Kelimeler: Diliçi çeviri, Şahıs bildiren yapılarda eksilti, Dil politikaları, Murasaki Shikibu, Klasik Japonca

\footnotetext{
${ }^{1}$ Dr., Asian Studies Center, esinesenacademia@gmail.com, Orcid: 0000-0002-8348-9125

Makale Türü: Araştırma Makalesi - Geliş Tarihi 12-01-2020- Kabul Tarihi: 31-03-2020

DOI:10.17755/esosder.673795
}

Atıf için: Elektronik Sosyal Bilimler Dergisi, 2020; 19(75):1148-1169 


\section{Introduction}

As a part of a main feature of Japanese, 'person referents' in a sentence are not generally verbalized unless they are necessary for communication. The term 'person referent ${ }^{2}$ is used in this study based on the previous studies to indicate all kind of person related elements in a sentence which may be "personal names, kinship terms, occupational titles, personal pronouns, (Iwasaki and Ingkaphirom, 20*05: 49 cited by Ishiyama, 2019: 134)" the words like hito [person/people etc.] or $k o$ [child/ boy/ girl/ plural form etc], etc. referring to third person as well as plural suffixes connected with a 'person referent' such as -tachi - $r a$, etc.

The above mentioned feature of Japanese is called as reader (listener) responsibility which is a language typology propounded by Hinds (2001). He states that in some languages like Japanese the "Reader must determine the textual relationships without help of overt markers" (Dimitrova, 2005: 158). Ellipsis in 'person referents' in Japanese exists diachronically and synchronically, though it shows some differences. Intralingual translations of classical texts form a good sample space to track these differences and the reasons why they differ in intralingual translations from different periods.

An intralingual translation is a translation within the same language (Jakobson, 1959: 233; Pârlog, 2019: 42) of written or spoken texts (Tahir Gürçağlar, 2011: 28), diachronically or synchronically (Tahir Gürçağlar, 2011: 28-29), which can be done as a direct or indirect translation (Pârlog, 2019: 42). Direct intralingual translation is done as "(a) rephrasing or reformulation, or (b) paraphrasing (Pârlog, 2019: 42). The indirect intralingual translation is done as (a) adaptation, or (b) free translation (Pârlog, 2019: 42).

The intralingual translations of classic Japanese texts are dealt with in terms of ellipsis in the previous studies. Fujii (1991), focusing on the subject ellipsis, compares the source text and different intralingual translations of the Tale of Genji [Genji Monogatari], which is written by the famous Japanese author Lady Murasaki (Nariyama, 2003: 29) and gathers the results presented in Table 1.

Table 1. Diacronic and Syncronic Changes in the Subject Ellipsis (Fujii, 1991 cited by Nariyama, 2003: 30)

\begin{tabular}{ccccccccc}
\hline Year & $\begin{array}{c}\text { Original } \\
1008\end{array}$ & 1723 & 1830 & 1914 & 1936 & 1959 & 1972 & 1978 \\
\hline $\begin{array}{c}\% \\
\begin{array}{c}\text { Subject } \\
\text { ellipsis }\end{array}\end{array}$ & 69.25 & 66 & 57 & 41,2 & 46,75 & 68.5 & 64.3 & 58 \\
\hline
\end{tabular}

This chart also indicates a great part of 'person referents' ellipsis in the text in different periods and its changes over time. Nariyama (2003: 30) based on Fujii (1991: 74-75) suggests that the changes in the period between 1910-1940 reflects the influence of Western languages.

Berk Albachten $(2013,2014,2015)$ in her works on intralingual translations put emphasis on the fact that the language may not be the main concern of all these translations. But also the effects of the other factors can be seen such as language policies, ideological stances etc. The author points out that "In intralingual translation, it is believed that reproducing the original is always possible and desirable. Thus, it seems to be considered a mechanical process whereby language is seen as a transparent medium, overlooking its political and ideological associations"

\footnotetext{
${ }^{2}$ In some studies for this term, 'personal references' is also used (Iwasaki and Ingkaphirom, 2005).
} 
(Berk Albachten, 2015: 176). In this sense, it is suggested that language use is modified by external factors.

This perspective also provides an important point of view to deal with intralingual translations in the Japanese case.

Wakabayashi (2019: 63) states that intralingual translations in "Japanese have long been an object of considerable attention", which includes not only the diacronic versions but also shifting the texts from a particular style or genre to another one. The diachronic intralingual translation of Japanese classics, beginning from 1700's "appealed to the diversifying readership who could not understand the classical language of the originals" (Wakabayashi, 2019: 63). After 20th century on, a growing interest for intralingual translations of Japanese classics has appeared, including many retranslations of the same works (Wakabayashi, 2019: 64).

My questions here are: why have so many different translations been made since the last century? What were the leading factors on the changes in these translations? Starting with these questions in this study, I will examine the differences in 'person referent' ellipsis in four different intralingual translations of a classical Japanese text The Diary of Lady Murasaki [Murasaki Shikibu Nikki] dating over four different periods. Although it seems very related to linguistic studies, my aim in this study is to present extralinguistic factors such as language policies, governmental policies of the period or impact of the translated literature within the literary polysystem etc., that affected the changes seen in the different intralingual translations with respect to 'person referent' ellipsis.

In this study, the excerpt titled "Nihongi no Mitsubune" [A nickname: Lady Chronicle] of the diary has been selected for the analysis due to the different types of 'attitudinal -expressions' [taigu-hyogen] which reflects different aspects of ellipsis in 'person referents'. This excerpt in four intralingual translations of Murasaki Shikibu Nikki [The Diary of Lady Murasaki] (See Table 2) for comparative analysis, dating 1918, 1933, 1954, and 1965 have been analyzed in terms of ellipsis in 'person referents'. Source text is Kurokawa-bon copy ${ }^{3}$ of the diary.

After 1868, language in Japan has changed drastically and still continues to change with the influence of different extralinguistic factors. On selecting sample space of intralingual translations for this study, I aimed to represent different phases of these changes. With this in mind, in the second chapter I have focused on extralinguistic factors linked to the changes in the Japanese language, which I have classified into the four main titles. I have limited my research until 1960's which represents the final drastic change in language after World War II. I have not only focused on the publication dates, but also on the dates such translators lived, including their education, knowledge of a Western language or their relations with the language policies of their period; and also the data on publishers and the different translation strategies representing the general approach of their times.

When focusing on translation strategies of intralingual translations in Japan we see three main streams: 1) texts on "the borderline between translation and commentary" (Clements, 2015: 80 cited by Wakabayashi, 2019: 64) which is common in older translations, 2) texts combining the original classic Japanese version with "modern translation [and] brief, easy-to-understand commentary" (Shirane, 2014: 140 cited by Wakabayashi, 2019: 64), and also vocabulary. In this

\footnotetext{
${ }^{3}$ In this study, the main source for classical Japanese text is the Murasaki Shikibu Nikki Kurokawa-bon Copy (Shikibu, 1970, 2008), the digital version of the text has been reached from the link below. Digital text of Murasaki Shikibu Nikki Kurokawa-bon copy: http://www.sainet.or.jp/ eshibuya/original55.html (accessed between: 8.2012- 11.2019).
} 
version, the texts may have format as follows: the classic Japanese text, translation, and commentary, vocabulary (older approach), or may have included the same page in the middle of the classic text with the vocabulary and commentary above and the modern Japanese translations at the bottom of the page (more common today), 3) the final version is the modern approach to the translations which are on the "borderline between translation and the writing of a new work" (Clements 2015: 80 cited by Wakabayashi, 2019: 64). These versions "moved well beyond a commentarial function, [... and are] noteworthy for the individuality brought to the process" (Wakabayashi, 2019: 64).

With the above mentioned perspectives, I have selected four intralingual translations of the diary of Lady Murasaki dating 1918, 1933, 1954 and 1965 (See Table 2).

Table 2. The Source Text and Intralingual Translations Dealt with in This Study

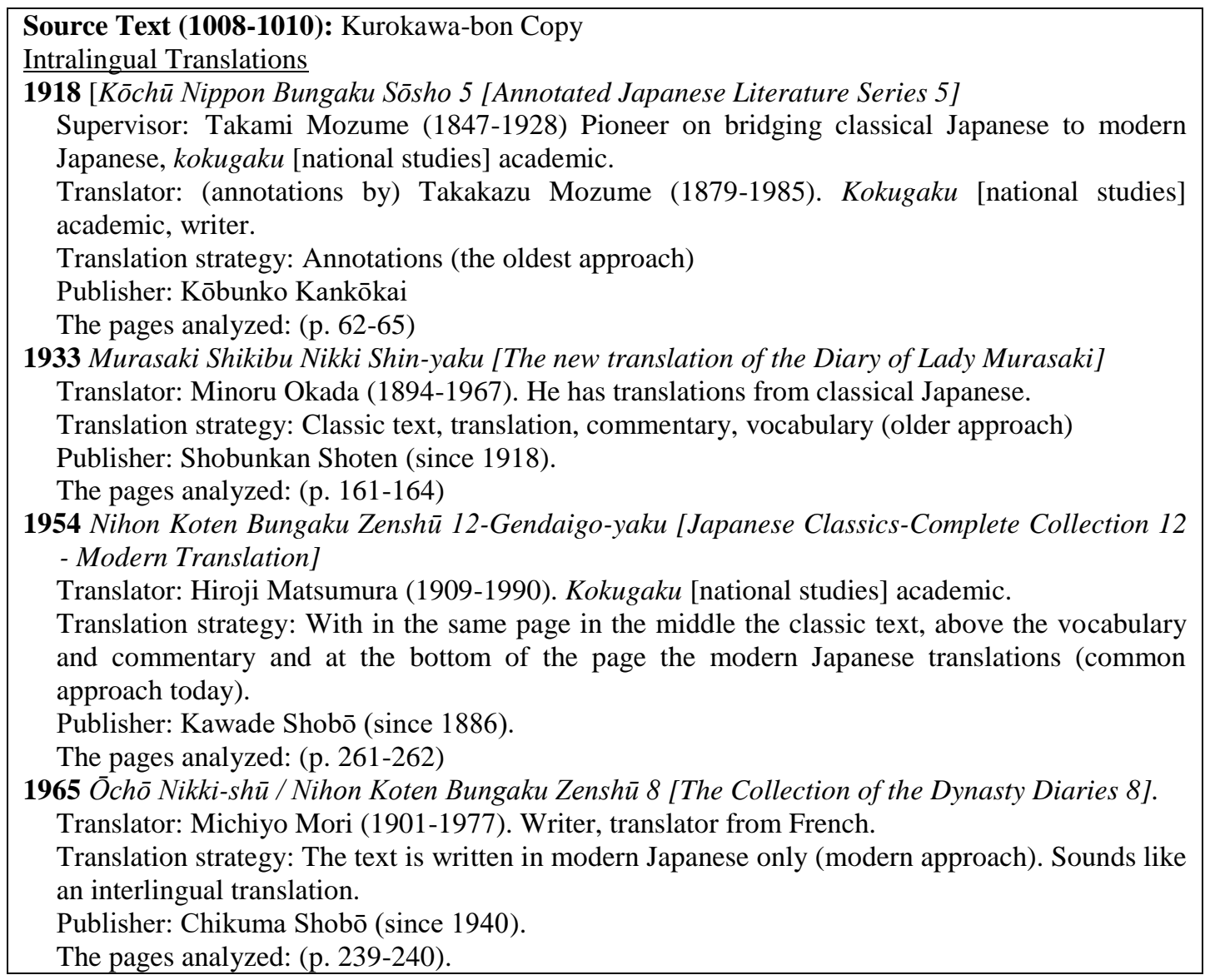

In previous studies it has been investigated in great detail the different aspects of 'person referents' (Lansisalmi, 2008: 238-241). Ellipsis also is a well studied and still discussed research area in Japanese studies (Clancy and Downing, 1987; Hinds, 1982; Ishiyama, 2019; Kameyama, 1985; Kuno, 1987; Nariyama 2003; Shibamoto, 1983; Vollan, 2016). On the interlingual translations of Japanese there are important recent studies such as Clements (2015), Sakai (2009) and Wakabayashi (2019). On the other hand, in Japan there are very limited studies on this subject [言語内翻訳] (Shinda, 2015, Zhu, 2009). So, I will suggest the same thing for the Japanese case as Berk Albachten suggested for the Turkish case that, in Japan "[...] the practice of intralingual translation that was born as a result of its implementation and since then has remained at the core of fervent discussions on linguistic issues and largely overlooked in 
theoretical discussions within translation studies" (Berk Albachten, 2015: 166)." Further studies on the intralingual translation in Japan can elucidate the extralinguistic factors that effected the translations; and can also contribute to a wider understanding of the reasons behind the differences in translations. This study will be the first to discuss Murasaki Shikibu Nikki [The Diary of Lady Murasaki] in terms of ellipsis in 'person referents' searching for the extralinguistic factors that effected the changes seen in the different intralingual translations with this respect.

\section{0's}

2. Extralinguistic Factors on the Changes in Japanese Language after 1868 to the

After the first direct contact with the West in 1868, the huge cultural flow affected all structures in Japan, including language. Each aspect related to language explained below is linked to the West, which may be in form of Western influence or opposition to this strong influence. I have dealt with these changes, dividing them in four main steps between 1868-1965.

a. Standard Language and Unification of Written and Spoken Languages:

After 1868, the Japanese government needed many reforms and changes in order to face the Western sanctions and also to respond to such sanctions. In relation to language, the Japanese government used it as a political device to unify the country (Twine, 2019: 170; 223) with "the creation of a national, standard language" which changed the language in two ways: 1) standard language; the "Unification of the different varieties of Japanese spoken through the country as, or under one national language (Frellesvig, 2010: 379)" affected the whole country when it took place in education after 1902 (Bolochilago, 2005: 32; cited by Özrenk Aydın, 2010: 68) and the NHK broadcasting after 1925 made these changes permanent in all over the country (Carroll, 2001: 62, cited by Özrenk Aydın, 2010: 82), 2) the "Unification, or alignment, of the spoken and the written language" [=genbun itchi] (Frellesvig, 2010: 379), a movement that appeared in the same period along with the standard language in Japan, until then the written language was totally different from the spoken language but still was the main device to connect people with different dialects all over the country.

\section{b. The Effect of the Contact with the Western Languages}

The influence of the Western languages had great effects on the Japanese language from 1868 on. I may suggest that these influences flow into the Japanese language in three main ways: 1) the direct influence of the specialized people who had direct contact with the West: a) the Japanese who had direct contact with Western countries: the Japanese government sent diplomatic or cultural missions and students to Western countries to "search for models that would be applicable for Japan in the process of rebuilding its institutions (Jansen, 2002: 355)". After their return to Japan most of them had positions which could affect language either in a deciding phase (such as on language policies) or application phase (such as teaching and translating). b) In addition to these Japanese people, in Japan, foreign specialists, advisers or teachers from Western countries were employed to build a modern nation before 1900's nearly 2400 (Kim, 2014: 58), 2) the effect of adaptation of the Western institutions: in Meiji Era, during 30 years, many Western institutions such as the "Navy and Post Office from Britain, Army and the criminal law from Prussia, civil law from France, the central bank from Belgium [...]" were adapted in Japan; also a mixture of German and French educational systems (Chang, 2007: 30) and many others. Along with the other developments there was a great flow in each field of the science including social sciences as well as technology and industry. All the terminology related to these institutions and different fields of knowledge were created in this period of the time 
[wasei-kango] (Baykara, 2014: 40, 45; Esenbel, 2012: 167; Labrune, 2002: 20, Maruyama and Katō, 2015; Yanabu, 2015), 3) the effect of literary translations from Western languages: literary translations from Western languages had great impact on Japanese language. They affected not only by means of the introduction of new terminology or new concepts but also through the introduction of new linguistic aspects such as the sentence structure (Baykara, 2014: 44-45; Maruyama and Katō, 2015; Yanabu, 2015: 204; Wakabayashi, 2019: 55).

\section{c. The Influence of Militarism and Greater Asianism}

Greater Asianism politics of Japan in 1930's was another factor that changed the Japanese language. Along with the politics of the period based on nationalist spirit, there was an opposition to the previous changes with respect to Western cultures. On the other hand, as a result of the Japanese expansionism politics in Asia, in order to unify the countries occupied by Japan, the Japanese government used the power of the kanji script, which resulted in many reforms including the simplification of the writing system that had been suspended, and on the contrary, a vast use of kanji was seen in this period. With the effect of the language policies in language and education there was a tendency to use older forms, words as well as kanji script (Özrenk Aydın, 2010: 83-84).

\section{d. American Influence after World War II}

After the defeat of Japan in 1945 in World War II, the allied power took control of the Japanese government and took steps on the contrary of the militarist government policies including language policies such as, diminutions of the number of kanji's, simplifying the writing system along with the radical changes in the educational system, including the text books. Besides, from this period on, an immense influence of English is seen on Japanese. This influence is seen even nowadays not only on the loan words from English that have entered and are used abundantly in Japanese but also English sentence structures such as the use of pronouns has influenced Japanese sentence structure (Bolochilago, 2005: 38; Carroll, 2001: 51, Özrenk Aydin, 2010: 62).

\section{The Diacronic and Syncronic Differences in the 'Person Referents' in Japanese}

There is no great gap between classical and modern standard Japanese because syntax presents only a few differences. The main differences are seen in derivation and the inflection of predicating forms. There are also some differences in vocabulary (Mathias, 1979: 501). The main feature of Japanese language, reader responsibility represents a similarity in classical and modern Japanese, which indicates that ellipsis in 'person referents' also represents similarity, but not the exactly the same statistically (Fujii, 1991; Nariyama, 2003).

Although this tendency of ellipsis in 'person referents', both in classical and modern Japanese there is "a relatively large number of first-person and second-person pronouns (Fukuzawa, 2017: 151, cited by Miyashita, 2019: 85)." Miyashita (2019: 86) describes as "essential in everyday life in Japanese society" to select appropriate personal pronouns, in relation to their social positions, or the gender of the speaker. Both in classical and modern Japanese ellipsis in 'person referents' can be deduced from other syntactical elements such as honorific language, sentence end particles, gender related words or contextual meaning and even sometimes by intuition (Nariyama, 2003: 4).

The differences in 'person referents' in classical and modern Japanese are as follows:

First person: both in classical and modern Japanese exists a large number of first person 
pronouns, however they are different such as $a[\mathrm{I}]$, aga/ waga [mine, I], ware [I], midzukara [me] and so on in classical Japanese (OKJ., 1988); watashi [I], watakushi, atashi [I (female speech)], boku [I (male speech)], jibun [I, mine], uchi [mine] and sometimes proper names [in womenchild speech], in modern Japanese. There are also archaic forms such as wagahai [=royal we], washi [I] that belong to the early modern era (KJN, 1996; OKJ, 1988). Although, in classic Japanese the demonstrative pronoun kono [this], which is utilized to indicate something close to speaker, is not categorized as personal pronoun, it was also used to indicate something related to speaker as "mine" which can also indicate second and third person (Lansisalmi, 2008: 238).

Second person: in classic Japanese, it was normally used with the person's title, or a word indicating the relations between the speaker and second person such as imo [wife] meaning 'my wife you", for saying "you" if not elliptic. But the real name of the person was never used, as it is used in modern Japanese, because in ancient and medieval period, calling someone with his or her real name was a kind of taboo related to kotodama [sprit of the word] belief. Whereas in modern Japanese, the speaker can use particular forms to indicate 'you' as the addressee's surname or name by adding honorific forms like -san instead of saying you. There are other personal pronouns such as anata [you (informal)], kimi [you (close)], otaku [you (polite)] along with many others. In old Japanese the word kimi was used by women addressing men with high status, meaning 'you my lord', but eventually it has changed. For second person plural, in classical Japanese most of the times it was elliptic, but plural suffixes such as -domo might be applied (OKJ., 1988). In modern Japanese plural suffixes such as -tachi, -gata can be applied.

Third person: In classic Japanese words as hito [person/ people], onna [woman/ women] etc, or title of the people, or the names of their assignments could be used, and for noble people adding the family name to the title or official assignment was also common. For noble women mostly the title/assignment of the husband or father was used. For third person plural, it was generally elliptic but the plural suffixes such as -domo -tachi were also applied. In modern Japanese, the pronoun kare [he], kanojo [she] has appeared as a result of the contact with Western languages as a translation for 'he' and 'she' respectively (Ishiyama, 2019: 55; Yanabu, 2015: 193-210). The words such as hito [person], hitobito [people], ano hito [that person], ano ko [that girl] are more common to indicate third person. Plural suffixes such as -tachi (more common), -ra etc., can be applied but most of the time it is elliptic. The use of hitobito [people] is also common.

\section{Sample Space, Four Intralingual Translations and Their Analysis}

\section{Sample Space}

Murasaki Shikibu Nikki [The Diary of Lady Murasaki] belongs to Murasaki Shikibu, who lived nearly one thousand years ago, is one of the most prominent women writers of the Japanese literature. She was a lady-in-waiting in the Empress Shoshi's court. She is best known as the author of The Tale of Genji [Genji Monogatari], which is often called the world's first novel. She was already well known as a novelist by the time she was in service at the court and she continued to write her diary during her service depicting not only the events of court life but also her interior world between 1008 and 1010.

For this study, an excerpt from the chapter titled "Nihongi no Mitsubune" [A nickname: Lady Chronicle] in the source text of the diary in classical Japanese has been analyzed in terms of ellipsis in the 'person referent'. Then the ellipsis in the 'person referent' of the source text has been compared to four intralingual translations and it has determined if they are translated as 
ellipsis or explicitly in the target texts.

In the excerpt, the author of the diary, Lady Murasaki, explains that there was a lady in waiting who gave her a nickname; Lady Chronicle (Shikibu 1996). This was because the emperor, while listening to her novel being read, mentioned that Murasaki must have read the chronicles of Japan, written in Chinese. In her time, Chinese was the language for state business and for men, and was not appropriate for a woman. She felt embarrassed because of this, saying that even in front of her own servants she acted like she did not understand Chinese writings. Then she narrates her childhood reminiscence. When she was a little girl, she had the habit of listening her brother's Chinese lessons and she used to grasp them quicker than her brother. So her father was complaining that it was a pity she was not a boy. For the final part she explains that she teaches Chinese to the empress in secret.

\section{Four Intralingual translations}

1918. The title of the book is Kōchū Nippon Bungaku Sōsho 5 [Annotated Japanese Literature Series 5]. In the first pages of the book, the following information is written: Supervision: Takami Mozume. Annotations: Takakazu Mozume. The two names are father and son respectively. In the last page of the book there is only Takakazu Mozume's name as author. The father Takami Mozume [物集高見] (1847-1928) is a kokugaku [national studies] academic on classical Japanese literature from a family dedicated on the same field. (KJN. 1998, MHJ. 1996). He is the one of the pioneers in his field bridging "the classical Japanese with modern Japanese language studies". (MHJ, 1996). He has a number of books on classical Japanese literature, dictionaries including the Kōbunko encyclopedia. The son, Takakazu Mozume [物集 高量](1879-1985) was also a kokugaku [national studies] specialist on classical Japanese literature as his father and grand father. He was a writer. He was 39 years old when this book was published and he was helping his father on the Köbunko encyclopedia since 1915. He has other annotated books of classic Japanese literature including Tale of Genji [Genji Monogatari]. (NMJ ., 2001).

The publisher of the book is Kōbunko Kankōkai [廣文庫刊行會]. Related to this publisher, there are entries in National Diet Library Catalog dating between 1916 and 1937 on classical Japanese literature and Kōbunko Encyclopedia by Takami Mozume.

The text: At the beginning of the book there is an introduction explaining Murasaki Shikibu and her work. The text of the book is in classical Japanese with furigana [syllabic characters, next to a kanji to indicate its pronunciation] written in hiragana syllabary. Above of the each page there are annotations on the text written by Takakazu Mozume. The text in classical Japanese indicates that, the language of the source text was still comprehensible in that period. Though the translator had to add information about not only the names, or other details related to Heian Period but also for the implicit parts of the text including 'person referent ellipsis'. The text represents somehow modernity in relation to language and the script, in comparison to previous books. For example, an $1890^{4}$ text has original text by hand writing with kana and kanji, and there were annotations in kanbun. In 1899 version $^{5}$, after the original text, the explanations with still somehow older language in hiragana and kanji take place.

1933. The title of the book is Murasaki Shikibu Nikki Shin-yaku [The new translation of

\footnotetext{
${ }^{4}$ https://dl.ndl.go.jp/info:ndljp/pid/1087770

${ }^{5}$ https://dl.ndl.go.jp/info:ndljp/pid/888891
} 
the Diary of Lady Murasaki]. The translator is Minoru Okada [岡田 稔] $\left(1894-1967^{6}\right)$. He has many books translated from Classical Japanese such as Man'yōshū.

Publisher of the book is Shobunkan Shoten [正交館書店] which was founded in 1918 and is still an ongoing company. A search on National Diet Library's data base revealed that until the end of the World War II, they have only intralingual translations of Japanese classics in the library catalog.

Text: The text features classical Japanese original with furigana, modern Japanese translation [tsūshaku 通釋] and vocabulary. At the beginning of the book there is hashigaki an explanation on this translation including such as source text or the target audience and kaidai explanations by translator which creates a background to understand the diary. The date in the introduction is 1932. The translation should have been completed before this date.

1954 The title of the book is Nihon Koten Bungaku Zensh $\bar{u} 12$ - Gendaigo-yaku [Japanese Classics - Complete Collection 12 - Modern Translation]. Translator is Hiroji Matsumura [松村博司] (1909-1990). He is an award winning kokugaku [national studies] academic on classical Japanese literature. He has several books on this field including annotated translations. (NMJ, 2001). He has another translation of Murasaki Shikibu Nikki [The Diary of Lady Murasaki] just one year after the publication of this book (Shikibu, 1955).

There is information on the book stating that the producer was the National Diet Library and the publisher: Kawade Shobō [河出書房] which is a company founded in 1886 and is still active today. A search on the database of National Diet Library reveals that until the date of this publication they have books such as world literature series with interlingual translations as well as intralingual translations of classics and research books on Japanese culture and magazines collected in the libraries catalog. The data implies that from the beginning of the language reforms in the Meiji period, in and after the war period they had close ties with government policies.

Text: At the beginning of the translation there is a part called "hisha no kotoba" [the authors word] (p. 205) by the translator. There is kaisetsu [expository comment] part at the end of the translation giving information on the diary and translation (p. 274) and another part called Murasaki Shikibu Nikki Keizu [pedigree chart] (p. 287). The text is formed as follows: the classic Japanese version and the translation with explanations at the bottom of the each page. The text suggests that for the translator to create a work to be easily understood, more than building an aesthetic text was required.

1965. The title of the translation is Ōchō Nikki-shū / Nihon Koten Bungaku Zenshū 8 [The Collection of the Dynasty Diaries- Japanese Classics - Complete Collection 8]. There is a previous translation with the same title and same contents dating $1960^{7}$. The translator is Michiyo Mori (1901-1977). She was also a writer, since she knew French, she wrote her own poetry in that language. She had lived in France and Belgium (NMJ, 2001).

The publisher is Chikuma Shobō [筑摩書房] founded in 1940 and still active today. A research in National Diet Library catalog revealed that they have books related to Western cultures such as world literature translations, world history, philosophy, today's world non-fiction

\footnotetext{
${ }^{6}$ http://webcatplus.nii.ac.jp/webcatplus/details/creator/59227.html

${ }^{7}$ https://iss.ndl.go.jp/books/R100000039-I000422670-00
} 
anthology and also related to Japan such as classic and modern Japanese literature, children books anthology by Japanese authors, and magazines so on.

Text: The translation is one of the five diary translations of classic Japanese in the same book. The text is formed as a Japanese modern text, there is no source text or explanatory notes on the translation. The wording of the book sounds like an interlingual translation. At the end of the book there are parts by different authors on the Heian women's literature (p. 371) and diary literature of the Japanese dynasty (p. 365).

\section{Analysis}

1st Sentence: 左衛門の内侍といふ人はべり。

[suB. Saemon-no-Naishi to iu hito] [v. haberi]

Saemon no Naishi as call person be POL. NPST

[Meaning: There is a person called Saemon no Naishi]

No ellipsis in 'person referents'. 2 'person referents'. (Title, hito)

2nd Sentence: あやしうすずろによからず思ひけるも、え知りはべらぬ心憂きしりうごとの多う聞こえはべ リし。

[Top. Ø] [A.AD. Ayashū suzuro ni] [Ø yokara-zu omohi keru mo],

(1.Saemon no Naishi) strange without reason C.PT. (2.me) good NEG. think PROG. INTERJECTION

[Meaning: Strangely without reason, she thinks about me not good]

[suB. Ø] [v. e shiri habera nu] [ов. kokoro-uki shiriugoto no ōu [v. kikoe haberi shi]

(3. I) NEG. know POL. SHK. PST. (unpleasant) gossip GEN. a lot hear POL. SHK. PST.

[Meaning: I didn't know that; (but) lots of unpleasant gossips are heard]

No person referents in the sentence.

1. Third person singular ellipsis [she=Saemon no Naishi, name of the lady in waiting]. This can be elliptic as an anaphora ellipsis in modern and classical Japanese because the name takes place in the previous sentence.

1918 No explanation given in the explanatory notes, it can be seen as elliptic 1933 sono hito ga [that person]

1954 ellipsis 1965 kono onna wa [this woman]

2. First person ellipsis [me]. This should be explicit in modern Japanese. (Obligatory explicitation 1).

1918 Murasaki Shikibu ni [about Murasaki Shikibu]. This explanation in the explanatory notes is valid for next ellipses. 1933 jibun ni [about myself] 1954 watashi wo [me] 1965 watashi no koto wo [about me]

3. First person singular ellipsis [I]. This can be elliptic in modern Japanese.

1918 Murasaki Shikibu ni [about Murasaki Shikibu] 1933 jibun wa [myself] 1954 watashi no [mine] 1965watashi wa [I]

3rd Sentence: 内裏の上の『源氏の物語』、人に読ませたまひつつ聞こしめしけるに、「この人は、日本 紀をこそ読みたるべけれ。まことに才あるべし」と、のたまはせけるを、ふと推しはかりに、「いみじうなむ才が る」と殿上人などに言ひ散らして、「日本紀の御局」とぞつけたりける、いとをかしくぞはべる。

[suB. Ø]

(4. Saemon no Naishi) 
[Meaning: She,]

[A.AD. uchi-no-ue no genji-no-monogatari hito ni yomase-tamahi tutsu kikoshimeshi keru ni] emperor's GEN. genji GEN. tale PT. read CAU. RES. listen RES. PROG. PT.

[Meaning: the emperor while making read aloud to some person and listen Genji Monogatari]

[A.AD. kono hito wa Nihongi wo koso yomi taru bekere. makoto ni zae aru beshi to, notamahase-keru this person chronicle of Japan ACC. even read PROG. CJ. really talent be CJ. that say RES. PST.

[Meaning: he said, this person should have been read Nihongi Chronicles, she really have talent]

wo futo oshihakari ni] [A.AD. "Imijiu nan zae-garu" to tenjōbito Ø nado ni iichirashite]

ACC immeaditly guess PT. great CJ. talent be that noble (5.PL.) etc. PT. spread CON.

[Meaning: (hearing this sentence) immediately (jump to conclusion) and spread it to the courtiers as (if I am boasting of to be) 'very talented']

[A.AD. Ø Nihongi-no-Mitsubone to zo] [v. tsuke tari keru]

(6. I) chronicle of Japan GEN.HON.lady-in-waiting to name SHK. PROG.

[Meaning: the nickname "Lady in waiting for Chronicles of Japan" is given to me.]

[A.AD. ito wokasiku zo] [v. haberu]

very funy EMP. be POL. NPST.

[Meaning: very funny]

3 'person referents' in the sentence. (uchi no ue (title), hito, kono hito)

4. Third person singular ellipsis (she $=$ Saemon no Naishi). This can be elliptic as an anaphora ellipsis in modern and classical Japanese because the name takes place in the first sentence.

1918 ellipsis 1933 ellipsis 1954 Naishi ga 1965 Saemon no Naishi wa

5. Third person plural ellipsis tenjotbito-tachi [courtiers]. No explicitation is needed in modern Japanese.

1918 ellipsis 1933 ellipsis 1954 ellipsis 1965 ellipsis

6. First person singular ellipsis [I, me]. This ellipsis is difficult to compensate in modern Japanese.

1918 Previous explanation in the explanatory notes helps to compensate this ellipsis [name] 1933 jibun ni [to myself] 1954 watashi ni [to me] 1965 watashi no koto wo [to me]

4th Sentence: この古里の女の前にてだにつつみはべるものを、さる所にてオさかし出ではべらむよ。

[Top.SUB. Ø] [A.AD. kono furusato no omuna Ø no mae nite dani tsutsumi haberu mono wo]

(7. I) this home town GEN. woman(8. PL.) GEN. in front LOC. even reserve POL. thing though

[Meaning: I reserve even in front of ladies (in waiting of my) hometown (=my own ladies in waiting)

[A.AD. saru tokoro nite] [овJ. zae sakashi]- [v. ide haberamu yo]

this-kind place LOC. learning wise display POL. NPST CJ. EMP.

[Meaning: would I display talent in this kind of place (=court)]

No 'person referent' is overt in the sentence. 
7. First person singular ellipsis [I]. It can be compensated from "kono" in classical Japanese but in modern Japanese explicitation is needed. (Obligatory explicitation 2).

1918 waga [mine] 1933 jibun wa [myself] 1954 watashi wa [I] 1965 jibun no [mine] Japanese.

8. Third person plural ellipsis omuna [women]. No explicitation is needed in modern 1918 ellipsis 1933 onna-tachi [women]1954 meshitsukai (elliptic ) [servant] 1965 meshitsukai-tachi [servants]

5th Sentence: この式部の丞といふ人の、童にて書読みはべりし時、聞き習ひつつ、かの人は遅う読みとり、

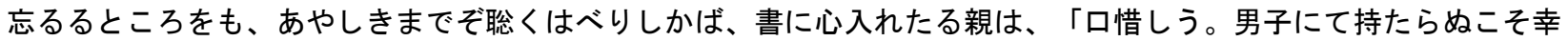
ひなかりけれ」とぞつねに嘆かれはべりし。

[A.AD... »Kono shikibu-no-jō to iu hito «no waraba nite fumi yomi haberi shi toki

this shikibu-no-jō as call person GEN. child in (Chinese-classics) read POL.PST. time

[Meaning: This secretary of Ministry of Ceremonial (= my brother) when (he) was a boy, reading Chinese Classics]

$\emptyset$ kiki-narahi tsutsu kano hito wa osō yomi-tori, wasururu tokoro wo mo

(9. I) listen-learn PROG. that person PT. late read-grasp forget RK. part ACC. also

[Meaning: I used to listen and learn (the lessons); even the parts this person learns late or forgets]

Ø ayashiki made zo satoku haberi shikaba]

(10. I) strange to EMP. grasp-quickly POL. PST.COND.

[Meaning: I used to grasp unusually quick.]

[Top.sub. fumi ni kokoro-iretaru oya wa]

(Chinese-classics) PT. enthusiastic RK. KNR. dad TOP.PT.

Meaning: My father who dedicated to Chinese classics (saying)]

[A.AD. "kuchioshiu Ø onokogo ni te motara nu koso Ø saiwahi nakari kere" to zo] regrettable (11. I) (12. her) boy PT. have SHK.KNR. EMP.(13. I) fortunate NEG. IZN. that EMP.

[Meaning: “(It is) regrettable that I haven't had her as a boy, I am not fortunate"]

[A.AD.tsune ni] [v. nagekare haberishi]

always grieve MZN. POL. PST.EMP.

[Meaning: was always grieving]

4 'person referents' in the sentence. (kono shikibu no jō (title), hito, kono hito, oya)

9. First person singular ellipsis [I]. In modern Japanese it can be compensated from contextual meaning. But in this sentence there are other implicit items so explicitation may be used, along with next ellipsis once is enough (Obligatory explicitation 3).

1918 mizukara [myself] 1933 ellipsis 1954 watashi wa [I] 1965 watashi wa [I]

10. First person singular ellipsis [I]. In modern Japanese it can be compensated from contextual meaning.

1918 ellipsis 1933 jibun wa 1954 ellipsis 1965 ellipsis

11. First person singular ellipsis [I]. No explicitation is needed in modern Japanese. 
1918 ellipsis 1933 ellipsis 1954 jibun [myself] 1965 ellipsis

12. Third person singular [her]. No explicitation is needed in modern Japanese.

1918 ellipsis 1933 kono ko ga [this child] 1954 kono ko ga [this child] 1965 kono ko ga [this child]

13. First person singular ellipsis [I]. No explicitation is needed in modern Japanese

1918 ellipsis 1933 jibun no [mine] 1954 jibun wa [myself] 1965 *

6th Sentence: それを、「男だに才がりぬる人は、いかにぞや。はなやかならずのみはべるめるよ」と、や うやう人の言ふも聞きとめて後、一といふ文字をだに書きわたしはべらず、いとてづつに、あさましくはべり。

[A.AD. sore wo] [A.AD. otoko dani zae-gari nuru hito wa, ikani zo ya?

in-spite-of this man even-like flaunt-learning person PT. how. EMP. Q.

[Meaning: But inspite of this, "How it should be even for men flaunting with his learning?

Hanayaka narazu nomi haberu meru yo, to]

beautiful be NEG. only POL. CJ. EMP that

[Meaning: It is not good at all" ]

[A.AD. yōyō hito Ø no iu mo kiki tomete nochi] [suB. Ø]

gradually person (14. PL.)GEN. say also hear-keep-in-mind after (15. I)

[Meaning: Gradually after I heard people saying (this kind of things)]

[A.AD. Ø ichi to iu moji wo dani kaki-watashi haberazu]

(16. I) one that say letter ACC. even write POL. NEG NPST

[Meaning: I don't write even the word "one"]

[A.AD. Ø ito tetsutsu ni] [A.AD. asamashiku] [v. haberi]

(17. I) very unskilled miserable POL.

[Meaning: I am miserably very unskilled (on writing)]

2 'person referents' in the sentence. (otoko, hito)

14. Third person plural ellipsis, hito. No explicitation is needed in modern Japanese

1918 ellipsis 1933 ellipsis 1954 ellipsis 1965 hito bito [people]

15. First person singular ellipsis [I]. It can be compensated from contextual meaning. Same reference with the next two ellipses.

1918 ellipsis 1933 ellipsis 1954 ellipsis 1965 watashi wa [I]

16. First person singular ellipsis [I]. It can be compensated from contextual meaning. Same reference with the previous and next ellipses

1918 ellipsis 1933 ellipsis 1954 ellipsis 1965 watashi wa / jibun kara [I, myself]

17. First person singular ellipsis [I]. It can be compensated from contextual meaning. Same reference with the previous ellipses

1918 ellipsis 1933 ellipsis 1954 ellipsis 1965 watashi wa / jibun kara [I, myself]

7th Sentence: 読みし書などいひけむもの、目にもとどめずなりてはべりしに、いよいよかかること聞きは ベりしかば、いかに人も伝へ聞きて憎むらむと、恥づかしさに、御屏風の上に書きたることをだに読ま顔をしはべ りしを、宮の御前にて『文集』の所々読ませたまひなどして、さるさまのこと知ろしめさまほしげにおぼいたりしか 
ば、いとしのびて人のさぶらはぬもののひまひまに、をととしの夏ごろより、「楽府」といふ書二巻をぞしどけなな がら教へたてきこえさせてはべる、隠しはべり。

[A.AD. Ø Yomishi fumi nado iikemu mono, me ni mo todomezu narite haberi shi ni

(18. I) read PST. (Chinese-clasics) say CJ. thing look NEG. become POL. PST. even

[Meaning: Although, I (avoid) even to look the Chinese-classics I used to read,]

iyo iyo kakaru koto kiki haberi shikaba

still-more this thing listen POL. PST. COND.

[Meaning: but still I heard this thing (she is talking about Saemon Naishi's gossip)]

ika ni hito Ø mo tsutaekikite $\quad$ nikumu-ramu to, hadzukashisa ni how person (19. PL.) also hear by hearsay (20. me) dislike CJ. that shamefulness PT.

[Meaning: with the shame (I felt for) how people may be talk and hear, and dislike me]

mi-byōbu no kami ni kakitaru koto wo dani yomanu kao wo shi haberishi wo] folding-screen GEN. (on) at writen thing ACC. even read NEG. face ACC. do POL. PST. though

[Meaning: I even act as is if I can't read the scripts in the folding screens, in spite of this]

[A.AD. Miya no o-mae nite, monshū no tokoro-dokoro Ø yomase tamai nado shite empress(ga) HON.presence at collected-works GEN. here-and-there (21. me) read PASS. RES. etc. do CON.

[Meaning: the empress made me read some parts of collected works in her presence]

\section{saru sama no koto shiroshimesa maoshige ni oboitari shikaba] $\varnothing$ [A.AD. ito shinobite]}

that- GEN. thing know RES. (want-PT.) PT. think PROG. do COND. (22. I) very refrain CON.

[Meaning When (her majesty) want this thing, with much refrain]

[A.AD. hito Ø no saburawanu mono no hima-hima ni, ototoshi no natsu-goro yori] person (23. PL.) (ga) serve NEG. thing GEN. (opening) PT. last-year GEN. summer around from

[Meaning: in the vacant times when people doesn't present at service (of her majesty), since the summer before last]

[овј. Gafu to iu fumi ni-kan wo zo]-

gafu as call Chinese-clasics two-volume ACC. EMP.

[A.AD. shidokenanagara]

slovenly-as

[Meaning: the Chinese classic called New Ballads in two volumes, slovenly]

[suв. Ø] [v. oshietate-kikoyesasete haberu] Ø [v. kakushi haberi]

(24. I) teach RES. listen PASS. RES. POL. (25. her) hide POL.

[Meaning: I teach and make her (Excellency) listen, I hid (this thing).

1 'person referent' is overt in the sentence. (miya)

18. 22. First person singular ellipsis [I], referring Lady Murasaki. In modern Japanese all can be compensated from contextual meaning. I will add here explicitation of first person singular in different parts of text, because one is enough to refer all. Only 22 is explicit.

1918 ellipsis 1933 jibun wa [myself] (22.) 1954 watashi wo [to me] (20.) 1965 watashi no koto [me] (20.)

19. Third person plural ellipsis hito. No explicitation is needed in modern Japanese 
1918 ellipsis 1933 hito bito ga [people] 1954 ellipsis (hito mo) 1965 hito bito [people]

20. First person ellipsis [me]. No explicitation is needed in modern Japanese.

1918 ellipsis 1933 ellipsis 1954 watashi wo [to me]1965 watashi no koto wo [me]

21. First person ellipsis [to me]. This ellipsis can be compensated from respectful language. No explicitation is needed in modern Japanese.

1918 ellipsis 1933 ellipsis 1954 ellipsis 1965 ellipsis

22. Please see 18. above.

23. Third person plural ellipsis hito no. No explicitation is needed in modern Japanese. 1918 ellipsis 1933 (jijo tachi) no [ladies in waiting] 1954 ellipsis 1965 (hoka no hitotachi) ga [other people]

24. First person ellipsis [I]. This can be compensated from respectful language [keigo].

1918 ellipsis 1933 ellipsis [keigo] 1954 ellipsis [keigo]1965 ellipsis [keigo]

25. Third person ellipsis [her]. This can be compensated from respectful language [keigo] and also it can be take place as an anaphora ellipsis because at the beginning of the sentence the word "empress" exists.

1918 ellipsis 1933 ellipsis [keigo] 1954 ellipsis [keigo]1965 ellipsis [keigo]

8th Sentence: 宮もしのびさせたまひしかど、殿も内裏もけしきを知らせたまひて、御書どもをめでたう書 かせたまひてぞ、殿はたてまつらせたまふ。

[A.AD. Miya mo shinobisase tamaishikado] empress also refrain RES. PST. but

[Meaning: Also the empress refrain(ed) but]

[A.AD. Tono mo Uchi mo keshiki wo shirase tamaite]

(lord) also (emperor) also situation ACC. know RES. CON.

[Meaning: Both the Regent and the Emperor (got) wind of the situation]

[овл. Ø Ø ō-fumi -domo wo medetō kakase tamaite zo]

HON. (26. they) (27. for empress) (Chinese-classics) PL. ACC. glamorous write PASS. RES. EMP.

[Meaning: (they) made written glamorous Chinese Classics (for her)]

[Top.sub. Tono wa] [A.AD. Ø] [v. tatematsurase tamau]

(lord) TOP.PT. (28. to the empress) give RES. RES. NPST.

[Meaning: (which) the regent present(ed) to the empress]

4 'person referents' in the sentence. (miya, tono, uchi, tono)

26. Third person plural ellipsis [they]. This can be compensated from respectful language [keigo] and also it can be take place as an anaphora ellipsis because at the beginning of the sentence "the regent and the emperor" exists.

1918 ellipsis 1933 ellipsis [keigo] 1954 ellipsis [keigo] 1965 ellipsis [keigo]

27. Third person singular ellipsis [for her]. This can be compensated from respectful language [keigo] and also it can be take place as an anaphora ellipsis because at the beginning of 
the sentence "the empress" exists both in classical and modern Japanese.

1918 ellipsis 1933 ellipsis [keigo] 1954 ellipsis [keigo] 1965 ellipsis [keigo]

28. Third person singular ellipsis: [to her=to the empress]. This can be compensated from respectful language [keigo] and contextual meaning.

1918 ellipsis 1933 ellipsis [keigo] 1954 chūgū e [to the empress] 1965 chūgū $n i$ [to the empress]

9th Sentence: まことにかう読ませたまひなどすること、はた、かのもの言ひの内侍は、え聞かざるべし。

[suB. Makoto ni $\varnothing \quad \varnothing k \bar{o} \quad$ yomase tamahi nado suru koto ]

really (29. the empress) (30. me) like-this read PASS. RES. etc. do thing

[Meaning: Really, (that) (the empress) makes (me) read (these books)]

[Top. kano mono-ii no Naishi wa] [A.AD. hata] [v. e kika zaru beshi]

that thing say GEN Naishi TOP. may-be NEG. hear NEG.RK. CJ.

[Meaning: Naishi, who is saying this kind of things (=gossips), might not have heard yet]

1 'person referents' in the sentence. (Naishi)

29. Third person singular ellipsis [she=the empress]. This can be compensated from respectful language [keigo] both in classical and modern Japanese.

1918 ellipsis 1933 chūg $\bar{u} g a$ [the empress] 1954 chūgū $g a$ [the empress] 1965 chīg $\bar{u} n i$ [to the empress]

30. First person singular ellipsis [me]. This can be compensated from respectful language [keigo] and from contextual meaning both in classical and modern Japanese.

1918 ellipsis 1933 chūgū ga kō shite kaseki wo o-yomi nasaru koto mo (different translation strategy, in this sentence the is no need for watashi) 1954 watashi $n i$ [to me] 1965 watashi ga [I] 1994 watashi $n i$ [to me]

り。

10th Sentence: 知りたらば、いかに誹りはべらむものと、すべて世の中ことわざしげく憂きものにはべりけ

[ $\varnothing \quad$ shiritaraba ika ni soshiri haberamu mono to $]$

(31. anaphora=she) know COND. how slander POL. CJ. thing as (think)

[Meaning: If she would have known (that) how (she would) have slandered!]

[suB. subete yononaka koto-waza ] [A.AD. shigeku uki mono ni] [v. haberi keri ]

all (world) occurence sad PT. POL.

[Meaning: All the occurrences in the world are so sad.]

No 'person referents' in the sentence.

31. Third person singular ellipsis [she]. This can be compensated from the previous sentence as an anaphora ellipsis both in classical and modern Japanese.

1918 ellipsis 1933 ellipsis 1954 ellipsis 1965 ellipsis

\section{Conclusion}

In this section, I have presented the statistical data gathered from the text analysis and then I have construed these data in the light of the extralinguistic factors that have been dealt with in the second chapter. The following results are reached: 


\section{Statistical data gathered from text analysis:}

Table 3 and 4 represent the overt and elliptic person referents in the classical Japanese text of the diary of Lady Murasaki. Table 5 presents the data related to elliptic and explicit translations of the ellipsis in the source text, including the words used for explicitation.

Table 3. Overt Person Referents in the Classical Japanese Text of the Diary.

\begin{tabular}{cccccc}
\hline First person singular & \multicolumn{3}{c}{ Third person singular } & Third person plural \\
\hline & $\begin{array}{c}\text { Family } \\
\text { words }\end{array}$ & Otoko & Hito & Title & \\
& & & &
\end{tabular}

\begin{tabular}{lllllll}
\hline Overt & None & 1 & 1 & 5 & 8 & None
\end{tabular}

Table 4. Elliptic Person Referents in the Classical Japanese Text of the Diary.

\begin{tabular}{ccccccc}
\hline & \multicolumn{2}{c}{ First person singular } & \multicolumn{2}{c}{ Third person singular } & \multicolumn{2}{c}{ Third person plural } \\
\cline { 2 - 6 } & $\mathrm{I}$ & $\mathrm{Me}$ & She & Her & Title & They \\
\hline Elliptic & 12 & 5 & 4 & 4 & 6 \\
\hline
\end{tabular}

Source text:

* 15 person referents are overt (33\%) in the source text dating 1008, whereas 31 elliptic person referents $(67 \%)$. The words like hito indicating third person plural were counted as elliptic.

* Despite the text implications regarding the employment of the first person singular and the third person plural there is no overt mention of them.

* 17 of 31 are first person singular ellipsis. 8 of 31 are third person singular ellipsis. Six of 31 are third person plural ellipsis.

Table 5. The Comparison of the Source Text and the Intralingual Translations with Respect to Elliptic and Explicit Translations

\begin{tabular}{|c|c|c|c|c|c|c|c|c|c|c|c|c|}
\hline \multirow{4}{*}{$\begin{array}{c}\text { ST } \\
1008\end{array}$} & \multicolumn{6}{|c|}{ First person singular } & \multicolumn{3}{|c|}{ Third person singular } & \multicolumn{3}{|c|}{ Third person plural } \\
\hline & \multicolumn{6}{|c|}{17} & \multicolumn{3}{|c|}{8} & \multicolumn{3}{|c|}{6} \\
\hline & \multicolumn{6}{|c|}{ Explicit } & \multicolumn{3}{|c|}{ Explicit } & $\varnothing$ & \multicolumn{2}{|c|}{ Explicit } \\
\hline & $\varnothing$ & jibun & watashi & mizukara & waga & name & $\varnothing$ & $\begin{array}{l}\text { Onna, } \\
\text { hito, ko }\end{array}$ & name & & tachi & bito \\
\hline 1918 & 12 & & & 1 & 1 & $2+1$ & 8 & & & 6 & & \\
\hline 1933 & 8 & $3+5$ & & & & & 6 & 1 & 1 & 3 & & 3 \\
\hline 1954 & 7 & 2 & $3+5$ & & & & 4 & 1 & 3 & 6 & & \\
\hline 1965 & 4 & 1 & $2+9$ & & & & 3 & 3 & 2 & 2 & 2 & 2 \\
\hline
\end{tabular}

Table 6. The Changes in the Translations of Elliptic Person Referents in Four Intralingual Translations

\begin{tabular}{ccccc}
\hline & 1918 & 1933 & 1954 & 1965 \\
\hline Elliptic & $64 \%$ & $46 \%$ & $55 \%$ & $30 \%$ \\
\hline Explicit & $36 \%$ & $54 \%$ & $45 \%$ & $70 \%$ \\
\hline
\end{tabular}

Target texts: 
* Only for 3 of the 31 ellipsis of the classical Japanese source text explicitation is obligatory in modern Japanese target texts. All these 3 are first person singular ellipsis. In other 28 ellipses, explicitation is non-obligatory.

* These 31 ellipses of the classical Japanese source text are represented as follows in the 4 different intralingual translations to modern Japanese (See Table 5 and 6).

In the 1918 intralingual translation 20 of the 31 ellipsis are remained elliptic $(64 \%)$ and 11 of them are translated (have annotations) explicitly (36\%).

In the 1933 intralingual translation, one ellipsis cannot be analyzed due to different translation strategies. 14 of the 30 ellipses are remained elliptic (46\%) and 16 of them are translated explicitly (54\%).

In the 1954 intralingual translation, 17 of the 31 ellipses are remained elliptic (55\%) and 14 of them are translated explicitly (45\%).

In the 1965 intralingual translation, one ellipsis cannot be analyzed due to different translation strategies. 9 of the 30 ellipsis are remained elliptic $(30 \%)$ whereas 21 of them are translated explicitly $(70 \%)$.

Although in 1933, 1954 and 1965 translations represent explicitation of third person singular or plural ellipsis, in none of them the third person pronouns kare or kanojo have been used. In the first two translations, there is no use of first person pronoun watashi, whereas the last two have abundant use of it. The 1918 and 1954 translations do not have explicitation of third person plural, whereas the 1933 and 1960 translations have.

The reasons behind the above mentioned statistical changes:

As can be seen from the above mentioned data, there are drastic changes between 10 to 20 years intervals of these intralingual translations rising then ascending with a maximum of $70 \%$ of and a minimum of $36 \%$ of explicitations. These changes cannot be explained by the natural changes in the language, but with extralinguistic factors.

*Comparing the 1918 translation with the previous translations mentioned in the study reflects the standard language and unification of the written and spoken language in annotations. We may associate this with the supervisor of the book, Takami Mozume, a pioneer who is seen as a bridge between classical and modern language. On the other hand, in the annotations there is no overt effect of Western languages, nor in the explicitations such as use of personal pronouns appeared with the effect of Western languages, or the extensive explicitations of 'person referent'. I may suggest that the 1918 annotated translation serves for a better understanding of the changing language within this period of time drastically, but the formation of the text with only commentary notes indicates that the classical Japanese was still comprehensible to the audience of that period. The data of the publisher, with many publications of annotated classic texts and with a pioneer encyclopedia on Japan related times, indicates that the publisher acts with the stream of government language policies.

*The 1933 translation is on the border line with previous language policies and militarist language policies as its date. The text reflects that the standard language and unifications in written and spoken language have been established strongly. The 54\% of explicitation indicates that the Western language influence began to enter the translation strategies, but the lack of use of words such as watashi [I], kare [he], kanojo [she] which were created or used as a result of the 
contact with Western languages, implies the resistance against Western cultures. And the use of jibun [me/my self] a more archaic form and ellipsis seen in the third person are closely related with militarist language policies of the period. The translation in the text implies that the ties with the classical Japanese have been loosened with the changes in language. The translator and also the publisher having many other intralingual translations of the classical Japanese implies that there was a demand for these kind of translations in that period most probably with the effect of the changing language caused by the language policies of that period.

*The 1954 translation shows a transition between militarist language policies to American occupation language policies in Japan. This text has less explicitation than the 1933 and 1965 texts. There is no explicitation of third person plural. Both reflect the effect of the militarism against the Western influence going back to origins of the Japanese culture including language. On the other hand, the remarkable use of the first person pronoun watashi indicates the effect of English language, and the effect of the translations from Western languages. The form of the text including original, modern translation and commentaries within the same page, which still dominates the intralingual translations today, can be seen an attempt to built and protect the close ties with the long standing past of the country. The language in the texts does not represent ancient or archaic air, but shows that the changes, such as standard language, unification in written and spoken language, were established entirely in this period. Most probably the translation was ordered by National Diet Library in war conditions, but could have been printed after the occupation. It is commonly seen that the translators of classical texts are kokugaku [national studies] academics like this translation whose main purpose is to create a comprehensible text rather than aesthetic one. He has other translations of classical Japanese. The publisher was established at the beginning of the changes in language and their publication policies seem to be related with the government policies.

As a result, this study presents that in nearly a 50 year time span between 1918 and 1965, in the intralingual translations there are drastic changes with respect to ellipsis in the "person referents'. Although it seems the changes in these translations are connected to linguistic studies, in fact other extralinguistic factors such as language policies, politics of the period, Western influence and translated literature which also had impacts on the translators and the publishers are closely related to these changes. Being a first study on this subject on Murasaki Shikibu Nikki [The Diary of Lady Murasaki], represents an important step to the contribution to the translation studies in the context of Japanese focusing on intralingual translations, also to the studies on Lady Murasaki and her diary, as well as the studies on classical Japanese literature

\section{References}

Baykara, O. (2014). Modern Japonya'nın Doğuşu ve Shiga Naoya. İstanbul: Boğaziçi Üniversitesi Yayınevi.

Berk Albachten, Ö. (2013). Intralingual translation as 'modernization'of the language: the Turkish case. Perspectives, 21(2), 257-271.

Berk Albachten, Özlem (2014). Intralingual Translation: Discussions within Translation Studies and the Case of Turkey A companion to translation studies. Bermann, S., \& Porter, C. (Eds.). John Wiley \& Sons. 573-585

Berk Albachten, Ö. (2015). The Turkish Language Reform and Intralingual Translation. Tradition, Tension And Translation In Turkey, 118, 165. 
Carroll, Tessa C. (2001) Language Planning and Language Change in Japan. Surrey: Curzon Pres, Richmond.

Clancy, P. M. Downing, P. (1987). The use of wa as a cohesion marker in Japanese oral narratives. Perspectives on topicalization: The case of Japanese wa. 3-56.

Chang, Ha-Joon. (2007). "Understanding the Relationship between Institutions and economic development" Institutional change and economic development. London: Anthem Press.

Clements, R. (2015). A Cultural History Of Translation In Early Modern Japan. Cambridge: Cambridge University Press.

Dimitrova, B. E. (2005). Expertise and explicitation in the translation process. USA. John Benjamins Publishing.

Esenbel, S. (2012). Japon Modernleşmesi ve Osmanlı. İstanbul: İletişim.

Frellesvig, B. (2010). A history of the Japanese language. Cambridge: Cambridge University Press.

Fukuzawa, M. (2017). Bungaku no Ninshō to Gengogaku no Ninshō. Tokyo: Bungaku-Gogaku.

Hinds, J. (1982). Ellipsis in Japanese. USA: Lingustic Research Inc.

Hinds, J. (2001). "Reader Versus Writer Responsibility:A New Typology", Landmark Essays on ESL Writing, s. 63-72, 2001.

Ishiyama, O. (2019). Diachrony of Personal Pronouns in Japanese: A functional and crosslinguistic perspective. USA. John Benjamins Publishing Company.

Iwasaki, S., Ingkaphirom, P., Horie, I. P. (2005). A reference grammar of Thai. Cambridge: Cambridge University Press.

Jakobson, R. (1959). On linguistic aspects of translation. On translation, 3, 30-39.

Jansen, M. B. (2002). The making of modern Japan. USA. Harvard University Press.

Kameyama, M. (1985). Zero anaphora: the case of Japanese. USA. Stanford Dissertation

Kim, H. (2014). Doctors of empire: medical and cultural encounters between imperial Germany and Meiji Japan. Toronto: University of Toronto Press.

KJN. Shinmura, I. (1998). Kojien. (5th edition). Japan: Iwanami Shoten.

Kuno, S. (1987). Functional syntax: anaphora, discourse and empathy. Chicago: The University of Chicago Press

Labrune, L. (2012). The phonology of Japanese. Oxford: Oxford University Press.

Lansisalmi, R. (2008). Teaching Personal Reference in Japanese Evidence and Counter-Evidence: Essays in Honour of Frederik Kortlandt, Volume 2. eds. Lubotsky, A., Schaeken, J., Wiedenhof, J., Derksen, R., Siebinga, S. USA. BRILL.

Maruyama, M.; Katō, Sh. (2015). Honyaku to Nihon no Kindai. Tokyo, Iwanami Shinsho.

Mathias, B. (1979). “Review”. Monumenta Nipponica, 34(4), 501-504.

MHJ. (1996). Maipedia Hyakka Jiten, Japan, Heibonsha.

Miyasahita, R. 2019. Translating the Turkish Personal Pronoun "Ben" into Japanese Role 
Languages. Shaping the Field of Translation in Japanese Turkish Contexts Voll. Berlin: Peter Lang.

NMJ. (2001). Nihonjin Meidai Jiten. Japan: Kodansha.

OKJ. (1988), Obunsha Kogo Jiten, Japan: Obuncsha.

Özrenk Aydın, G. (2010). Türkiye'deki ve Japonya'daki Dil Politikalarına Genel Baklş. Ankara: Ankara Üniversitesi, Sosyal Bilimler Enstitüsü, Yayınlanmamış Yüksek Lisans Tezi.

Nariyama, Sh. (2003). Ellipsis and Reference Tracking in Japanese. USA: John Benjamins Publishing.

Pârlog, A. C. (2019). Intersemiotic Translation: Literary and Linguistic Multimodality. USA. Springer.

Sakai, N. (2009). How do we count a language? Translation and discontinuity. Translation Studies. 2. 71-88.

Shibamoto, J. S. (1983). Subject ellipsis and topic in Japanese. Research on Language \& Social Interaction. 16(1-2), 233-265.

Shikibu, M. (1918). Kōchū Nippon Bungaku Sōsho 5, Trans. Mozume, T. Japan: Kōbunko Kankōkai

Shikibu, M. (1933). Murasaki Shikibu Nikki Shin-yaku, Trans. Okada, M. Japan: Shobunkan Shoten

Shikibu, M. (1954), Nihon Koten Bungaku Zenshū 12 - Gendaigo-yaku, Trans. Matsumura, H. Japan: Kawade Shobō.

Shikibu, M. (1955). Murasaki Shikibu Nikki, Trans. Matsumura, H. Japan: Kōbundō

Shikibu, M. (1965). Ōchō Nikki-shū / Nihon Koten Bungaku Zenshū 8. Trans. Mori, M. Japan: Chikuma Shobō

Shikibu, M. (1970). Murasaki Nikki-Kurokawabon. Japan: Kasama-shoten, 1970.

Shikibu, M. (1996). The Diary of Lady Murasaki. Trans. R. Bowring. New York: Penguin Classics.

Shikibu, M. (2008). Murasaki Shikibu Nikki. Izumi Shikibu Nikki, Murasaki Shikibu Nikki, Sarashina Nikki. Tokyo: Shōgakukan.

Shinda, Y. (2015). Honyaku, Yōyaku ni okeru Umi no Yuragi ni tsuite. Dai 77 kai Zenkoku Daikai K ōen Ronbunshu. (1), 13-14.

Shirane, H. (2014). Mediating the Literary Classics: Commentary and Translation in Premodern Japan. Rethinking East Asian Languages, Vernaculars, and Literacies. USA.: Brill. p. 129-146.

Tahir Gürçağlar, Ş. (2011), Çevirinin $A B C$ 'si. İstanbul: Say Yayınları.

Twine, N. (2019), Language and the Modern State: The Reform of Written Japanese. Routledge, London.

Vollan, A. Ellipsis in Japanese. Master's thesis, Oslo: Oslo University, 2016. 
Wakabayashi, J. (2019). Japanese Conceptualizations of 'Translation'. A World Atlas Of Translation. Vol. 145. eds. Gambier, Yves, and Ubaldo Stecconi. USA.: John Benjamins Publishing Company.

Yanabu, A. (2015). Honyakugo Seirtsu Jijo. Tokyo: Iwanami Shinsho.

Zhu, W. (2009). Shika ni okeri Gengonai Honyaku no Kanōsei ni kansuru Kōsatsu. Bungaku Kenkyūshü. (27), 19-30. 